\title{
Factors Influencing Students' Achievement in Form 5 Islamic Studies Subject
}

\author{
Mohd Aderi bin Che Noh ${ }^{1}$, Noraini binti Omar ${ }^{2} \&$ Hasnan bin Kasan ${ }^{2}$ \\ ${ }^{1}$ Department of Methodology and Educational Practice, Faculty of Education, National University of Malaysia, \\ 43600 UKM Bangi, Selangor, Malaysia \\ ${ }^{2}$ Centre for General Studies, National University of Malaysia, Selangor, Malaysia \\ Correspondence: Mohd Aderi bin Che Noh, Department of Methodology and Educational Practice, Faculty of \\ Education, National University of Malaysia, 43600 UKM Bangi, Selangor, Malaysia. Tel: 60-038-921-6642. \\ E-mail: aderi@ukm.my
}

Received: February 4, 2013 Accepted: March 1, $2013 \quad$ Online Published: July 22, 2013

doi:10.5539/ies.v6n8p83 URL: http://dx.doi.org/10.5539/ies.v6n8p83

\begin{abstract}
This study is aimed at analyzing the factors influencing the achievements of students in the subject of Islamic Studies for Form 5 SPM (KBSM) in schools in the area of Samarahan, Sarawak. The factors analysed is attitude and interest. This is a survey based study and data was compiled from the survey forms which had the topic "Factors influencing Students' Achievement", which consisted 26 items and 1 set of questions with 40 items to measure the achievements of students, which comprised of 200 Form 5 students from five (5) schools in the district of Samarahan. Five students involved as interviews' respondents in this study. Interview technique was also utilised to analyse and clarify the issues under study. Data analysis were performed using software Statistical Packages For Social Science (SPSS) involving frequency, percentage, mean and standard deviation. The research found that interested did not have significant relationship with the achievement of the students while the attitude factor has a significant relationship with the students' achievement in the subject of Islamic study.
\end{abstract}

Keywords: influences, achievement, Islamic studies

\section{Introduction}

Islamic Studies as a subject is made mandatory on Muslim students and was incorporated into the official school schedule from the year 1962. It was enforced pursuant to the provisions of the Education Act 1961 which was based on the reports of a study conducted by the Education Committee 1960 stated:"Rules should be made to teach Islam to assisted schools with not less than 15 Muslim students".

\section{Background of the Study}

The comments made by Datuk Abdul Rafie Mahat, the former Director-General of Education, was studied in relation to the result of the Sijil Pelajaran Malaysia (SPM) 2002 which showed deterioration by six percent compared to the previous year, which made it the second consecutive year since 2001 when a 4.9 percent decline from the year before. What was even sadder was when Datuk Abdul Rafie Mahat, disclosed that the decline was due to the extremely poor mastery of fardhu ain matters. The same factors were quoted by him when he commented on the decline of the same subject the previous year.

Many studies had been conducted in relation to the factors affecting the performance of students in various subjects. Based on studies conducted by Fitt (1957) in Auckland, New Zealand, it was found that the relationship between the students' attitude towards the subject, has a positive effect on the performance of that subject. This was found after he employed a question and answer technique amongst the 1244 students in the city. Mat Darus Othman (1992) in his studies also found that attitude was tied to the performance in the subject of Economy. According to Abdul Halim Mohammad and Wan Mohamad Wan Sulong (2006), in their "Study Between a Student's Interest and Attitude Towards Arabic Language: A Case Study on the Bachelor of Arabic Students at the Public Institutes of Higher Learning in Malaysia" (Kajian Antara Minat Dan Sikap Pelajar Terhadap Bahasa Arab: Satu Kajian Kes Ke Atas Pelajar Sarjana Muda Bahasa Arab Di IPTA Malaysia) had found that attitude and interest of students were important to determine their success. 
In this study, the researchers had combined two models, specifically Kemp and Smellie (1997) and Gersten (1998) and chosen two factors to link with the achievement of the students in Islamic Studies, which are interest and attitude of the students, to support the conceptual framework of this study. This is because to the researcher, interest and attitude influences the motivation for a student to study. Based on the foregoing, the conceptual framework was as per Figure 1.

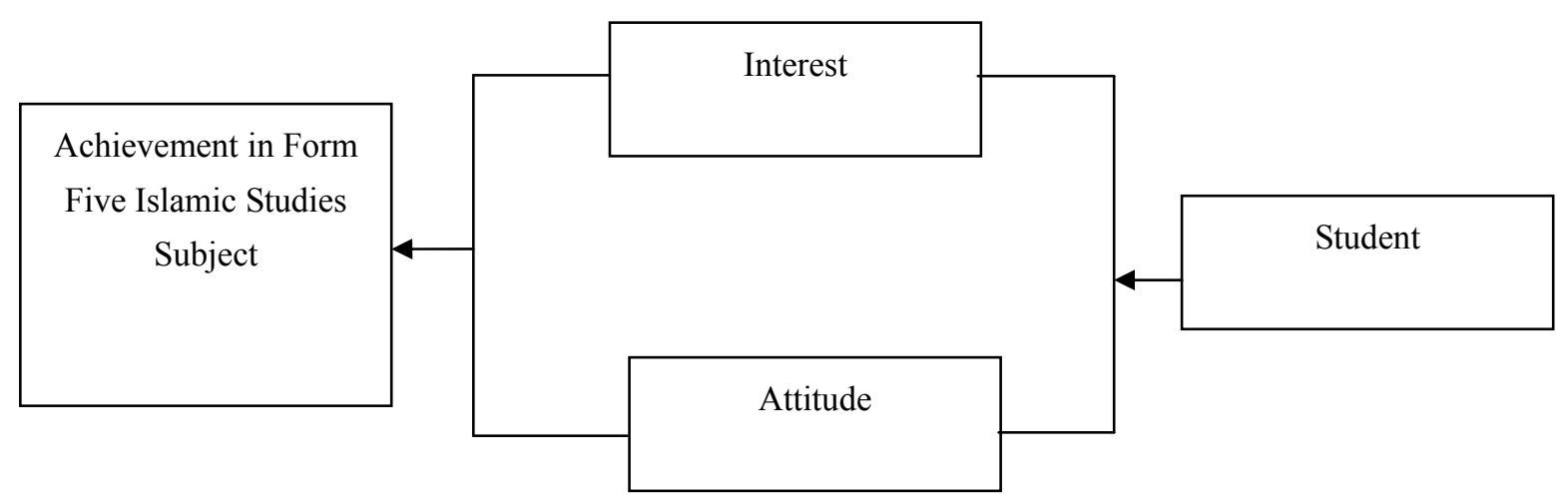

Figure 1. Conceptual Framework of the Research

\section{Objectives of the Study}

Specifically, the study's objectives were:

a. Identify the level of achievement of the students, in the subject of Form 5 Islamic Studies;

b. Identify the level of interest of the students in the said subject;

c. Identify the students' attitude towards the said subject;

d. Identify the link between interest and the students' achievements in the said subject; and

e. Identify the relationship between attitude and the students' achievements in the said subject.

\section{Questions of the Study}

Through this study, the researchers sought answers for each of these questions:

a. Identify what the students' achievement levels were for Form 5 Islamic Studies?

b. What is the level of interests of the students in the subject?

c. What are the students' attitudes towards Islamic Studies?

d. What is the relationship between interest and the students' achievement in the subject of Form 5 Islamic Studies?

e. What is the relationship between attitudes and the students' achievement in the subject of Form 5 Islamic Studies?

\section{Literature Review}

\subsection{Interest and Attitude}

Various findings of studies had been put forward to explain the factors that influenced students in the subject of Islamic Studies. Several studies that had been conducted showed that many factors influence a student's performance either from the aspect of cognitive, attitude or motivation. Similarly, there have been studies which found the connection between the elements of teachers, methods of teaching, experience and attitude. According to Suradi (1987), the attitude of a student towards his teacher, subject or other courses taken will determine the interest and thus the efforts towards academic success of a student.

Interest is connected to attitude. If a person is interested in a subject matter, he will have a positive attitude towards it. This will produce something meaningful and effective. However, sometimes interest does not correlate to a person's attitude. (Syed Hashim and Sharipah Khadijah 2001). A student who is interested in science but too lazy to do any science experiments would not succeed in becoming a scientist. Interest is also closely connected to self-motivation. Hashim (2000) held that overall, interest is a motivational variable. Interest is vital to learning as interest may lead to motivation driving the student in the classroom. Similarly the studies 
of Mc Clelland et al. (1953) found that the motivation of success is desire (interest) to be successful in a certain standard. The motivation of achievement is often measured by way of Thematic Apperception Test or TAT. This test comprised of many factors which encouraged success. In this situation what makes work fun is the work itself. Statements such as "...this is my interest", or "This has been my interest since before" are verbalization of internal motivation. Foo (1988) also stated that the presence of a deep interest in a student towards any specific subject will drive that student to work hard and diligently towards achieving excellence in that subject.

Attitude existed with man since birth. Attitudes are the soul or light within the body. Allport (1967) stated that attitude is a preference of a person which influences his actions. It is a mental readiness and experience, which drive individual actions towards a certain stimulus. When an individual likes something or otherwise, agrees or otherwise on any particular matter, that individual is said to have positive or negative attitudes on that particular matter. According to Aminah (2008), in her studies she has found that the Malay students' attitude towards learning is discouraging with 73 percent disliking additional training, 50 percent failed to complete their homework and 48 percent too dependent on the teacher (Utusan Malaysia, June 17, 2008). Katz (1964) had discussed the role of attitude at length and he held the view that the role of attitudes can be linked to changes in attitudes. He said attitudes can change with the presence of incentives and penalties. Consequently he submitted four changes in attitudes, being, instrumental function, the ego-defence attitude, the ego-expressive and the knowledge function. These attitudes strongly influenced the changes in an individuals' attitude. To them, ideology is a wide cognitive system which determines habit. For Fishbein and Ajzen (1978) the theory of attitude originates from belief and attitude and grew to include behaviour and has to be measured by linking the subject to the belief which shows agreement or otherwise.

\subsection{Studies on Interest and Attitude}

\subsubsection{Study on Interest}

Researchers in the field of education in this country have long studied on the factors of interest that has been linked to the achievement of students in a particular subject. The study of "Between the Students' Interest and Attitude Towards Arabic Language: A Study on the Bachelor of Arabic Students at the Public Institutes of Higher Learning in Malaysia" (Antara Minat dan Sikap Pelajar Terhadap Bahasa Arab: Satu Kajian Ke Atas Pelajar Sarjana Muda Bahasa Arab Arab Di IPTA Malaysia) by Mohd.Mansor Daud (2003) discovered that $62.5 \%$ students were not interested in learning Arabic. This was because $45 \%$ of them continued their studies in Secondary Religious School (Arabic) due to family pressure and most of them held the view that Arabic was difficult to master. A study by Siti Nurhanim (2006) found that generally, the students' interest was critical to measure the effectiveness of the teaching and learning process in any subject.

The study conducted by Zarin Ismail and Abd.Halim Tamuri (2006), found that the interest of students in mass media resources for Islamic studies, general knowledge, and education gave a positive impact on their values and also perception of the teaching of Islamic studies at their school. Aiiri (2003), surveyed the aspect of interest of a student towards Islamic Studies, and found that $54.5 \%$ of them had said they were less interested in this subject while $54.7 \%$ said it was boring. A majority of the students agreed that they were not interested in the subjects because the curriculum was hard to understand and also due to the factor of one way teaching (teacher-centric). Hadiah Senin (1997), in her studies of factors influencing the students' performance in History, carried out on 250 students including Malay, Chinese and Indian from five schools in Batu Pahat, Johor had found that students who did well in the subject of History were those who were actually interested in the subject.

\subsubsection{Studies on Attitudes}

Che Basar (1986), who conducted a study on the response and effectiveness of Islamic education at the Sultan Abdul Halim College, Jitra, Kedah had found that 77.7 percent of students had shown a positive attitude and interest in the subject of Islamic studies. Only a small number of students were absent from class due to their involvement in outside activities. In his research, Abdullah Hassan (1987:653) found that most study and teaching programmes were produced more as a result of the earnestness and attitude of the students learning, that what is taught formally. According to Isma'il Sini, a good student in the aspect of his reflexes, intelligence, energy and feedback, can play a role towards the success of a learning programme. The study by Ab. Halim Mohamad and Wan Mohamad Wan Sulong (2003) called "Study between a Student's Interest and Attitude towards Arabic Language: A Case Study on the Bachelor of Arabic Students at the Public Institutes of Higher Learning in Malaysia" had found that the students' interest in the said language was high. The study conducted by Arham et al. (2006) in the form of descriptive explanations and survey using a quantitative approach on factors which influence the academic excellence of students of University Technology Malaysia, found that the attitudes of students towards learning could also contribute towards academic excellence. 
However, the students did not show attitude that are compatible with their course. Khalid (2002) stated about the internal influence on actions, achievement, and others on the individual. The study found that there was a significant relationship between the attitude and achievement of the student. This study also found that one of the main reasons why a positive attitude is required towards any particular subject is that attitude would have a motivational impact towards the students. If a person has a positive attitude towards learning any particular subject then he would study that subject in depth.

\section{Research Methodology}

In carrying out this study, the researchers used a combination of both qualitative and quantitative methods. The quantitative method was used to analyse factors of achievement in the subject of Islamic studies, whereas qualitative methods were used to garner responses from students on the strength of any of the listed factors, which included the factors of interest and attitude of students towards the subject of Islamic Studies. This study herein was carried out by way of survey and also semi-structured interviews. The information of this study was gathering via questions and answers. The method of survey was to compile data to describe, compare or explain attitude, knowledge or practice.

\section{Findings and Discussions}

\subsection{The Achievement Level of Students in the Subject of Form 5 Islamic Studies}

To answer this question, the researchers have found that the achievements of the students are at an average level. This supports the study by Robiah Sidin (1994) who said that the higher the marks obtained, the nearer a student is to achieve excellence. The results of the study found that achievement levels of students in respect of the subject of Form 5 Islamic Studies for five schools were good.

Table 1. The achievement levels of students in the subject of Islamic Studies

\begin{tabular}{llll}
\hline The level & Grade & Frequency & Percentage \\
\hline Excellent & 1A & 23 & 11.5 \\
Good & 2A & 28 & 14.0 \\
& 3B & 42 & 21.0 \\
Average & 4B & 37 & 18.5 \\
& 5C & 24 & 12.0 \\
Poor & $6 \mathrm{C}$ & 14 & 7.0 \\
& $7 \mathrm{D}$ & 13 & 6.5 \\
Failure & $8 \mathrm{E}$ & 09 & 4.5 \\
Total & $9 \mathrm{G}$ & 10 & 5.0 \\
\hline
\end{tabular}

Table 1 clearly shows that out of 200 students, 51 students or $25.5 \%$ achieved excellence in this subject, while 79 students or $39.5 \%$ had "good" marks. There were 38 students $(19 \%)$ in average, and 22 students $(11.0 \%)$ had poor grades, with 10 students obtaining the failure grade $9 \mathrm{G}(5.0 \%)$. In conclusion, if seen from percentage, it can be seen that the achievement levels of students in Islamic Studies for SPM for these five schools remains good.

\subsection{The Level of Student Interest in the Subject of Form 5 Islamic Studies}

One of the aims of this study was to identify the students' level of interests in Islamic Studies. Table 2 shows the mean and standard deviations for interest levels in the subject of Islamic Studies. 
Table 2. Mean and standard deviations for interest levels in the subject of Islamic Studies

\begin{tabular}{lll}
\hline Item & Mean & S.D \\
\hline 1. Interested in learning I.S & 4.54 & .64 \\
2. Happy to be able to learn I.S & 4.60 & .61 \\
3. I like to learn I.S & 4.43 & .64 \\
4. I.S affects my life & 4.47 & .64 \\
5. I.S is an important guide & 4.72 & .53 \\
6. I.S aspect causes declining results & 3.55 & 1.21 \\
7. I.S is very boring & 4.39 & $.80 \mathrm{~s}$ \\
Total Mean & $\mathbf{4 . 3 8}$ & $\mathbf{. 4 7}$
\end{tabular}

*Notes: Indirect

Table 2 shows the mean and standard deviation distribution of the students' interest towards Islamic Studies. Questions and Answers used utilised a Likert 5 point scale from " 1 " to " 5 ". These items in the interest measuring instrument all had high mean with a range of between 4.39 to 4.72 while the overall mean and standard deviation was 4.38 and .47 respectively. The results show that the interest levels of the students are high. The findings reflect that students still agree to the statement that they are interested in the subject of Islamic Studies. Through an interview with Respondent 1, he said,

"I am interested in studying Islamic Studies as I am interested to learn more about Islam. As a Muslim I must comply with Islamic teachings... silence... ahem... and I am also interested as I feel I should study Islam".

When asked if he was interested in the subject of Islamic Studies, Respondent 2 stated:

"Yes...," he answered confidently and added "very interested".

"As studying Islamic Studies is easy to understand, easy to score and relate to our own religion... it is not merely to pass exams".

"Because we learn new things we did not know before, so if the religious teachers (Ustaz and Ustazah) teaching or others, I am indeed interested... for example in Form 5, I can learn about the topic of marriage... I am absolutely interested and happy..."

The students' interests in the subject of Islamic Studies arose not only to pass the SPM exams but arose due to their feeling that taking Islamic Studies and learning about the religion is an obligation. This is very important in the environment of the community especially in the light of today's situation where many students are involved in social ills, as was mentioned by Abdul Halim and Khadijah (2003): It cannot be denied that the downfall of faith and occurrence of social ills such as apostasy, pre-marital sex, rape and failure of Muslim youths to fulfil their basic obligations as a Muslim had led to the perception in the community against the subject of Islamic Studies generally and the teachers of Islamic Studies specifically.

\subsection{Students' Attitude towards Islamic Studies as a Subject}

The study also aims to identify the students' attitudes towards Islamic Studies as a subject. Table 3 shows the mean and standard deviations in respect of students' attitude towards Islamic Studies as a subject. 
Table 3. Mean and standard deviations in students' attitude towards Islamic studies

\begin{tabular}{lll}
\hline Item & Mean & S.D \\
\hline 1. I.S interests me & 4.14 & .73 \\
2. Determined to get an 'A's & 4.42 & .72 \\
3. Actively participate & 4.05 & .77 \\
4. Intends to study I.S in depth & 4.35 & .73 \\
5. I complete my notes & 3.93 & .85 \\
6. Malay Language (BM) is more interesting than I.S & 3.06 & .76 \\
7. School is more interesting without I.S & 4.37 & .88 \\
Total Mean & 4.04 & .78 \\
\hline
\end{tabular}

Table 3 shows the distribution of mean and standard deviations of students' attitude towards Islamic Studies. Questions and Answers employed utilised a 5 point Likert scale from " 1 " to " 5 ". All the items in this attitude measuring instrument have a high mean with the range of between 3.06 to 4.37 and a total mean to be 4.04 . This shows that the students had a very positive attitude towards Islamic Studies as a subject. They were still positive and motivated in learning about Islamic Studies. The students participating in the Islamic Studies related activities, aimed to obtain an 'A's, aimed to further study in depth, and in fact did not feel bored of learning the subject. This statement is supported by the answer of Respondent 1:

"For me, no... not boring".

Confidently and looked me in the eyes when asked on his determination to get an 'A' grade. The Respondent stated:

"Yes".

Respondent 2's statement;

"I often do want...but I only failed once i.e. last year when I received 38 marks".

When asked if "is Islamic Studies as a subject, very boring"?

“...er... it depends on the teacher, for example, if the teacher only reads to us, of course it is boring... because no one understands what is being taught... but overall I feel that this subject is not boring... whether it is or not, depends on the teachers' delivery".

To identify the relationship between interest and attitude of students, and the achievements in Form 5 Islamic Studies subject, the Pearson-r correlation test was conducted. The test results are as displayed in Table 4.

\subsection{Relationship between Interest and the Students' Achievement in Form 5 Islamic Studies Subject}

Table 4. Results of the correlation test of interest and attitude variable with the students' achievement

\begin{tabular}{llc}
\hline Variable & \multicolumn{2}{l}{ Achievement in Islamic Studies } \\
\hline & $\mathrm{r}$ & $\mathrm{p}$ \\
Interest & 0.109 & 0.123 \\
Attitude & $0.144^{*}$ & 0.042 \\
\hline
\end{tabular}

$\mathrm{r}=$ pearson co-relation $\mathrm{p}=$ significant

$* 2$ ways significant $\mathrm{p}<0.05$

As shown in Table 4, the study results found that there is no significant relationship between interest of a student and his achievement in Islamic Studies as a subject $(\mathrm{r}=0.109, \mathrm{p}>0.05)$. This finding supports the view of Mc Clelland et al. (1953), which states that interest sometimes do not align itself with a person's attitude. A student who is interested in science but too lazy to do any science experiments would not succeed in becoming a scientist. However, there are other studies contradicting this. This is shown in the research done by Hadiah Senin (1997) in the study of factors influencing a students' performance in the subject of History, involving 250 
students including Malay, Chinese and Indians from five schools in Batu Pahat Johor, which found that students with good marks were those who were interested in the subject.

The findings of the study conducted by Zarin and Ab. Halim (2006), shows that students' interest in mass media sources relating to Islamic Studies, general knowledge and also education positively impacts on the values held and their perception on the teaching of Islamic Studies in their school. This is also in contradiction with the findings of the interview where the respondents said that the interest factor had influenced their achievements in the subject of Islamic Studies. The highest mean for each item was 4.72 with highly interested students or students who had strongly agreed to say that Islamic Studies is important as guidance in life. The statement of Respondent 2 when asked, if Islamic Studies affect his life? The respondents answered, "Yes...it has positive effects on my life.... an example is the importance of prayers...God Willing I will do five times....aa... what else.. manners with the elders, (behaviour) with the environment. So the Islamic Studies do teach us". Although the study found that no significant relationship existed between the factors of interest and the students' achievements in Islamic Studies, if we see from the aspect of the theory, interest will come as a result of a person's internal feelings which may influence his movements and can change a person's attitude. A person who is interested would naturally be motivated to learn something. Interest is usually closely connected to a person's attitude, whereby attitude is usually influenced by internal factors such as interest and preferences to what holds one's interest, and it is this interest that will lead to how thought and actions occur. In this respect, why would there be no significant relationship between interest and the achievement of a student?

\subsection{Relationship between Attitude and Students' Achievement in Form 5 Islamic Studies Subject}

The findings of the study in Table 4 shows that there is a significant relationship between the students' attitude and their achievement in Islamic Studies as a subject $(\mathrm{r}=0.144, \mathrm{p}<0.05)$. However, the relationship is at a low level. The study also found that one of the major factors why positive attitude is urgently needed, because attitude will effect motivation of the students. If a person has a positive attitude towards any subject, they will learn more about the subject. This finding is also compatible with the study carried out by Chakravathy (1969), on Malay students at Alam Shah Secondary school which discovers that there was a relationship between the students' attitude and achievement. Her studies found that the arts stream students' attitudes were significantly connected to their results whereas for science stream students there was no significant relationship between attitudes and achievement. The results of this study was the opposite of that done by Kamisah et al. (2007) which focused on scientific attitudes and its relationship with the attitude towards the subject of science. The studies found that there was no significant relationship between scientific attitude and attitude towards the subject of science.

\section{Summary}

Based on the findings of the study and the questions, it is clear that the achievement levels of the students in the subject of Islamic studies were good. Students were found to be very interested and had positive attitudes towards the subject. The research also found that the variables studied, i.e. interest did not have any significant relationship with the achievements of the students while the attitude factor, has a significant relationship with the students' achievement in the subject of Islamic Studies. This variable should be developed to achieve better results in Islamic studies amongst the students.

\section{Implication and Proposals}

The process of teaching and learning in schools must be improved further, so that a student's interest and attitude continues to be stimulated throughout the process of learning. This can simultaneously help towards the achievement of excellence of Malay Muslim students.

This simple study found that a students' attitude has significant relationship with his achievements, compared to interest. Hence these studies should be done to find what the real factors influencing their achievements in order to overcome the decline in results.

From the study conducted, the researcher proposes the following:

\section{Sampling}

The sampling for this study must be expanded in order to give significant answers to any research question in this study. The sample selection can also be broadened to cover other schools whether in the area of Samarahan so the findings of the study can provide input to a more generalized and wider range of population. The sampling must also take into account the characteristic aspects representing the population. The samples must also be given a thorough explanation so that they can provide proper feedback and not half hearted answers. This will affect the resulting findings of the study. 
The Authorities (The Sarawak Education Department and the Malaysian Ministry of Education)

The researchers suggest that the authorities are able to provide more effective modules for teaching and learning so that the students are more interested to learn Islamic Studies as a subject. The provision of interactive teaching accessories has been proven to attract the interest of students to learn this subject. The study has found that interest has no significant relationship with the achievement in Islamic Studies as a subject. This contradicts with many other studies which stated that the deeper a person's interest, the higher his achievements in that subject will be. Theoretically, (Woolfolk 1998) defined interest and efforts as aspects which affect the learning success of a student. However, sometimes interest is not in line with attitude. A student who is interested in science but too lazy to do any science experiments would not succeed in becoming a scientist. The researcher feels that this occurs due to the carelessness of the respondents in answering the questions relating to interest.

\section{References}

Abd. Halim Mohamad, \& Wan Mohamad Wan Sulung (2003). Study Between a Student's Interest and Attitude Towards Arabic Language: A Case Study on the Bachelor of Arabic Students at the Public Institutes of Higher Learning in Malaysia. Islamic Studies Discourse (Series 5). Islamic Studies and Arabic Language the Catalyst of Muslim Civilisation. Faculty of Education. National University of Malaysia, Bangi.

Abdul Halim Tamuri, \& Zarin Ismail (2006). The Relationship between Moral and Islamic Studies: A study amongst Youths in Sabak Bernam, Selangor. Islamic Studies Discourse (Series 5). Islamic Studies and Arabic Language the Catalyst of Muslim Civilisation. Faculty of Education. National University of Malaysia.

Abdul Halim Tamuri, \& Khadijah Razak (2003). The Teaching of Akhlak at Secondary Schools: Students' Perception. The Proceedings of Discourse on Islamic Studies (Series 3). The Method of Teaching Islamic Studies: Between Tradition and Innovation. Faculty of Education. National University of Malaysia.

Aiiri Abu Bakar. (2003). Students' Attitude towards Islamic Studies as a Subject: A Study in Schools of Alor Gajah, Melaka. Masters in Education thesis. Faculty of Education. National University of Malaysia.

Ajzen, I., \& Fishbein, M. (1977). Attitude behaviour relationship: A theoretical analysis and review of empirical research. Psychological Bulletin. http://dx.doi.org/10.1037/0033-2909.84.5.888

Allport, G. W. C. (1967). Attitudes. In Reading in an attitudes theory and measurement. M. Fishbein. New York: John Wiley and Son.Inc.

Aminah. (2008). Utusan Malaysia. (June 16, 2008).

Arham Abdullah, Baharin Mesir, \& Ahmad Muhaimean Mohamad (2006). Factors contributing towards the Academic Excellence of Students at the University Technology Malaysia. Seminar Paper of National Student Development Conference (NASDEC) 2006, 8-9 August 2006, Kuala Lumpur, Malaysia.

Chakravathy. (1969). A Study of attitudes of Malayan students towards mathematic. Thesis. University of Malaya.

Che' Basar. (1986). Islamic Studies in ordinary secondary schools: Case study at the Sultan Abdul Halim College, Jitra, Kedah. Thesis. National University of Malaysia.

Fitt, A. B. (1990). An Experimental Study of Children's Attitude to School in Auckland, New Zealand. British Journal of Psychology, 57, 25-30.

Foo Siet Chooi. (1998). Relationship between Attitude, Gender and Mastery of Basic Mathematics Concepts, and the Achievement in Modern Mathematics for Arts Stream Students. Thesis. National University of Malaysia.

Gardner, H. (1985). The frames of mind: Theory of multiple intelligences. New York: Basic Books.

Gersten, R. (1998). Recent advances in instructional research for students with learning disabilities: An overview. Learning Disabilities Research \& Practice, 13, 162-170.

Hadiah Senin. (1997). Factors influencing students' performance in History as a subject. Research Project for Masters in Education. National University of Malaysia, Bangi.

Hashim Andimori. (2000). Factors influencing the selection of civil engineering amongst UTM Students. UTM Degree project. Unpublished.

Jerrold E. Kemp, \& Don Smellie (1997). Planning, Producing and Using Instructional Technologies (7th ed.). Allyn \& Bacon. 
Kamisah Osman, Zanaton Haji Iksan, \& Lilia Halim. (2007). Attitude towards science and scientific attitudes amongst the Science students. Education Journal, 32, 39-60.

Katz, T. (1964). Review of Evidence Relating the Effect of desegregation on the intellectual performance of Negroes. American Psychologist, 19, 16. http://dx.doi.org/10.1037/h0040569

Kenworthy, L. S. (1992). Guide To Social Studies Teaching. Belment: Wadsworth.

Mat Darus Othman. (1992). Factors Influencing the Achievement of Quality in Form 6 Economic Subject. Masters Dissertation. Faculty of Education. National University of Malaysia.

Mc Clelland et al. (1953). The achievement motive. New York: Appleton - Century - Crofts. http://dx.doi.org/10.1037/11144-000

Mohd Mansor Daud. (2003). Study Between a Student's Interest and Attitude towards Arabic Language: A Case Study on the Bachelor of Arabic Students at the Public Institutes of Higher Learning in Malaysia. Master's Thesis in Faculty of Education. National University of Malaysia.

Siti Nurhanim Abd Halim. (2006). Studies on aspects influencing the interest of Form Four Students in Chemistry Subject in Rural Areas of Kota Star, Kedah. Practical Training. Faculty of Education, UTM. Unpublished.

Suradi Salim. (1987). Survey on attitude and habits of secondary school students of Negeri Sembilan. Education Journal, 11, 77-90.

Syed Hashim, \& Sharipah Khadijah. (2001). Interest, attitude and readiness of teachers towards the use of computers in learning and teaching. Practical Training for Masters. Tun Hussein Onn University Technology College.

Woolfolk A. (1998). Educational psychology (8th ed.). Boston: Allyn \& Bacon.

\section{Copyrights}

Copyright for this article is retained by the author(s), with first publication rights granted to the journal.

This is an open-access article distributed under the terms and conditions of the Creative Commons Attribution license (http://creativecommons.org/licenses/by/3.0/). 